FKIP Universitas Kuningan

\title{
KEMAMPUAN BERBAHASA DALAM PRAKTIK BERBICARA PADA PENGIDAP SKIZOFRENIA
}

\author{
Muhammad Ramdlan Al-Mubarrok, Susi Machdalena, Tb. Ace Fachrullah \\ Magister Linguistik Umum, Fakultas Ilmu Budaya, Universitas Padjadjaran, \\ Kota Bandung, Jawa Barat, Indonesia \\ muhammad15267@mail.unpad.ac.id
}

\begin{abstract}
ABSTRAK: Tujuan dari penelitian ini ialah untuk mengetahui kemampuan berbahasa yaitu kemampuan reseptif dalam hal menyimak dan mengutarakan jawaban serta kemampuan produktif dalam berbicara. Metode dan teknik yang digunakan dalam penelitian ini ialah teknik simak libat cakap dan catat, serta menggunakan menggunakan teknik cakap pancing yang merupakan suatu teknik yang diwujudkan dengan cara pemancingan karena untuk mendapatkan data tersebut peneliti harus memancing informan agar mau berbicara. Selain itu juga, penulis menggunakan metode padan organ wicara-fonetis artikulatoris yang menjadi alat ucap, penelitian yang menganilisis pada organ bicara manusia yang mengkaji terkait ujaranujaran fonetis. Hasil analisis menunjukkan bahwa gangguan berbahasa yang ditemukan pada pasien skizofrenia antara lain ialah: (1) penghilangan fonem awal, tengah, maupun akhir, (2) penambahan dan pengurangan fonem-fonem tertentu, (3) pengulangan fonem-fonem khususnya pada fonem tengah, (4) kesalahan peggunaan kategori preposisi dan konjungsi, serta (5) ketidaktepatan kosakata dengan ujaran informan karena faktor pengaruh bahasa Ibu atau bahasa asing yang dikuasai oleh informan.
\end{abstract}

KATA KUNCI: skizofrenia; fonologi ; reseptif ; produktif

\section{LANGUAGE ABILITY IN SPEAKING PRACTICES OF SKIZOFRENIANS}

ABSTRACT: The purpose of this study was to determine language skills, namely receptive abilities in terms of listening and expressing answers and productive abilities in speaking. The methods and techniques used in this study are the technique of observing proficiently and taking notes, and using the skillful fishing technique, which is a technique that is realized by fishing because to get the data the researcher has to provoke the informant to want to talk. In addition, the writer also uses the equivalent method of articulatory speech-phonetic organ which is a tool, a research that analyzes the human speech organ which studies related phonetic utterances. The results of the analysis show that the language disorders found in schizophrenic patients include: (1) removal of initial, middle, and final phonemes, (2) addition and subtraction of certain phonemes, (3) repetition of phonemes, especially in middle phonemes, (4) misuse of prepositional and conjunction categories, and (5) inaccuracies in vocabulary with the informants' utterances due to the influence of their mother tongue or foreign language controlled by the informant.

KEYWORDS: schizophrenia; phonology; receptive; productive

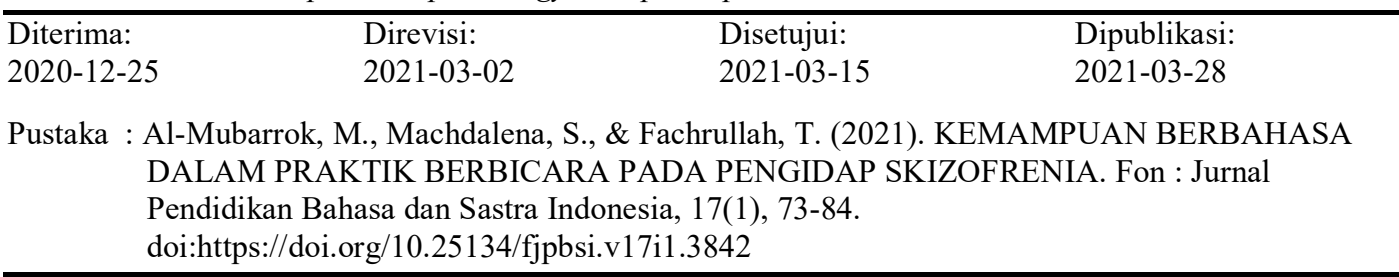

\section{PENDAHULUAN}

Bahasa

merupakan

alat

komunikasi yang bersifat arbitrer yang digunakan oleh anggota-anggota masyarakat untuk saling berhubungan dan berinteraksi. Bahasa ialah perantara untuk menyatakan pikiran, perasaan dan kemauan dari seseorang kepada orang lain, baik secara langsung maupun tidak langsung serta dengan cara lisan atau tulisan, melalui sebuah tanda simbol atau isyarat. Sebagai sarana komunikasi bahasa haruslah bisa memberikan simpulan dari pikiran dan perasaan untuk menyampaikan makna kepada orang lain. Sejalan dengan bahasa sebagai alat untuk 
berkomunikasi, manusia merupakan makhluk sosial yang setiap aktivitasnya perlu berbicara dengan orang sekitar, berangkat dari pemikiran itulah bahasa amat menjadi penting peranannya dalam kehidupan.

Tak terkecuali manusia pada umumnya, manusia dengan gangguan kesehatan pun khususnya gangguan mental seperti skizofrenia perlu berinteraksi dengan lingkungan sekitar. Walaupun secara logika akan sangat kesulitan dalam mengungkapkan perasaan dan ujaran yang ingin disampaikan. Tetapi hakikatnya pengidap skizofrenia perlu untuk berkomunikasi dengan sekitarnya. Berdasarkan data Riset Kesehatan Dasar (Riskesdas) 2018 menunjukkan, prevalensi skizofrenia di Indonesia sebanyak 6,7 per 1000 rumah tangga. Artinya, dari 1.000 rumah tangga terdapat 6,7 rumah tangga yang mempunyai anggota rumah tangga (ART) pengidap skizofrenia. Penyebaran prevalensi tertinggi terdapat di Bali dan DI Yogyakarta dengan masing-masing 11,1 dan 10,4 per 1.000 rumah tangga yang mempunyai ART mengidap skizofrenia/psikosis. Sementara itu, untuk daerah Jawa Barat sendiri prevalensi sebenarnya mencapai $0,14 \%$ dikali dengan jumlah penduduk Jawa Barat 49 juta, itu sekitar total ada sekitar 69 ribu mengidap gangguan mental termasuk skizofrenia. Data ini cukup terbilang banyak dan akan bertambah tiap tahunnya, jika dibiarkan akan berpotensi mengalami lonjakan yang lebih banyak lagi. Maka oleh itu, perlulah pemahaman akan kondisi seperti apa yang dirasakan oleh para pengidap skizofrenia agar bisa diterapkan dalam proses penyembuhan dan pengobatan, cara untuk mengetahui perasaan dari pengidap skizofrenia ialah memahami yang mereka ucapkan melalui praktik berbicara. Karena sudah tentu apabila secara mental pengidap skizofrenia itu terganggu, hal tersebut berpengaruh pada kemampuan berbahasa mereka yang juga terganggu. Gangguan berbahasa inilah yang akan menjadi sorotan dalam penelitian ini.

Gangguan

berbahasa sesungguhnya merupakan hal menarik untuk dikaji secara mendalam. Gangguan berbahasa melibatkan berbagai disiplin ilmu, juga memerlukan perlakuan atau penanganan tersendiri. Penanganan itu diberikan oleh para ahli di bidangnya, seperti medis, psikolog, dan linguis agar kemampuan berbahasanya berkembang. Arifuddin (2013: 288) berpendapat gangguan berbahasa itu dapat dibedakan atas tiga golongan, yaitu (1) gangguan berbicara, (2) gangguan berbahasa, dan (3) gangguan berpikir. Ketiga gangguan itu masih dapat diatasi jika pengidap gangguan itu mempunyai daya dengar yang normal. Bila pengidap gangguan berbahasa memiliki daya dengar yang tidak normal tentu penyembuhannya akan menjadi sukar bahkan sangat sukar. Ganggauan berbahasa akibat gangguan berpikir dialami oleh pengidap skizofrenia. Kajian gangguan bahasa oleh pengidap skizofrenia berkenaan dengan bidang kedokteran, khususnya neurobiologi dan patologi, bidang psikologi, serta bidang linguistik khususnya psikolingustik. Penelitian gangguan berbahasa dari sudut psikologi dan kedokteran telah sering dilakukan, namun dilihat dari sisi lingusitik tampaknya masih jarang dilakukan.

Dalam ilmu bahasa, kajian yang membahas lebih rinci mengenai suatu perkembangan bahasa yaitu kajian psikolinguistik. Secara etimologi kata psikologi berasal dari bahasa Yunani Kuno psyche dan logos. Kata psyche berarti "jiwa, roh, atau sukma", sedangkan kata logos berarti "ilmu". Jadi, psikologi secara harfiah berarti "ilmu jiwa", atau ilmu yang objek kajiannya adalah jiwa. Adapun kata linguistik lazim diartikan sebagai ilmu bahasa atau ilmu yang mengambil 
bahasa sebagai objek kajiannya (Chaer, 2015, hlm. 2-4). Dari pengertian kedua disiplin ilmu tersebut dapat disimpulkan bahwa pengertian psikolinguistik menurut Levelt (dalam Mar'at, 2015, hlm. 1) adalah suatu studi mengenai penggunaan bahasa dan perolehan bahasa oleh manusia. Ada tiga bidang utama dalam kajian ilmu psikolinguistik, sebagai berikut.

(1) Psikolinguistik umum ialah pengamatan atau peresepsi orang dewasa tentang bahasa dan cara memproduksi bahasa. Hal ini juga melandasi kemampuan perkembangan kognitif untuk menggunakan bahasa.

(2) Psikolinguistik perkembangan berisi pembahasan mengenai psikologi pemerolehan sistem bahasa pada anakanak ataupun orangtua, serta akan dibahas tentang perkembangan bahasa anak juga proses pembelajaran bahasa anak agar dapat mengurangi interfensi antara dua bahasa.

(3) Psikolinguistik terapan merupakan pengaplikasian dari teoriteori tentang pemerolehan, produksi, dan perkembangan bahasa pada anak-anak atau orang dewasa. Bidang terapan ini selanjutnya akan terus bercabang dan berkembang sesuai kebutuhan.

Menurut Arifuddin (2013, hlm. 114-152), pada umumnya seorang anak semakin hari akan terus berkembang menjadi lebih dewasa, perkembangan anak akan terus maju sesuai dengan usia mereka diiringi kemampuan-kemampuan lainnya. Begitupun dengan kemampuan berbahasa, anak-anak akan memperoleh bahasa permulaan mereka baik dari keluarga maupun lingkungan sekitar, selain adanya proses memperoleh mereka pun mengalami proses memproduksi bahasa. Pada pembahasan sebelumnya telah dikemukakan bahwa psikolinguistik dibagi ke dalam tiga bidang utama dan salah satunya adalah psikolinguistik perkembangan yang dilengkapi oleh psikolinguistik terapan.

Dalam psikolinguisik perkembangan akan dibahas secara mendalam terkait proses pemeroleh bahasa serta gangguan dalam berbahasa ketika bahasa berproses menjadi ujaran. Adapun gangguan berbahasa yang diderita oleh pengidap skizofrenia ialah gangguan berbahasa akibat gangguan berfikir. Menurut Arifuddin (2013, hlm. 289) gangguan berpikir (thought disorder) hanya mengacu kepada gangguan yang terjadi dalam pikiran dan menggunakan pikiran untuk memilih, atau lebih tepatnya, cara berpikir, sebagaimana yang terefleksi dalam ujaran, saling terikat dalam bahasa. Gangguan tersebut tidak untuk menggambarkan gangguan yang berkaitan dengan isi ujaran. Seseorang dikatakan mengalami gangguan berpikir apabila kita sebagi pendengar atau lawan tuturnya bingung atau tidak memahami wacana yang disampaikan atau diceritakannya. Ujuran yang mengalami gangguan dirincikan oleh kurangnya perencanaan dan pengecekan kebenaran ujran. Kelemahan ini ditengarai sebagai efek dari adanya gangguan fungsi lobus depan otak. Adanya gangguan atau cedera pada bagian tertentu pada lobus depan dapat disebabkan perubahan perilaku, dan kerusakan pada bagian-bagian tersebut sering memengaruhi fungsi bagian lain pada otak.

Untuk menentukan kemampuan reseptif dan produktif, diperlukan assement dan instrument penelitian. Menurut Tarigan (2015, hlm. 2), komponen penilaian kemampuan berbahasa Indonesia pada seseorang haruslah meliputi empat komponen keterampilan yang terbagi ke dalam kemampuan reseptif dan produktif yaitu (1) keterampilan menyimak (listening skill), (2) keterampilan berbicara (speaking skill), (3) keterampilan membaca (reading skill), (4) keterampilan 
menulis (writing skill). Setiap komponen itu erat sekali hubungannya dengan ketiga komponen lain serta memiliki bobot $25 \%$ dari $\quad 100 \%$ pada masing-masing komponennya dalam memperoleh kemampuan berbahasa Indonesia. Begitupun pada pengidap skizofrenia komponen penilaian ini dapat digunakan dengan isntrumen penelitian yang tepat dan akan dibahas secara rinci dalam penelitian ini.

Psikolinguistik mengenal skizofrenia sebagai gangguan berbahasa akibat gangguan berpikir. Seorang pengidap Skizofrenia dapat berbicara terus-menerus. Ocehannya hanya merupakan ulangan curah verbal semula dengan tambahan sedikit-sedikit atau kurang beberapa kalimat. Sebelum diganggu halusinasi (biasanya halusinasi auditronik), bahasa para pengidap skizofrenia ini tampak terganggu. Pada tahap awal pengidap skizofrenia ini mengisolasikan pikirannya. Tidak banyak berkomunikasi dengan dunia luar, tetapi banyak berdialog dengan diri sendiri. Ekspresi verbal terbatas, tetapi kegiatan dalam dunia bahasa internal (berbahasa dalam pikiran diri sendiri sangat ramai). Oleh karena itu, gangguan ekspresi verbal skizofrenia tahap awal ini menyerupai mutisme elektif. Skizofrenia merupakan penyakit mental yang paling umum, dan paling serius karena menimpa satu dari seratus orang. Penyakit ini dapat menimpa pria dan wanita. Pada pria gejalanya muncul pada akhir usia remaja dan awal usia dua puluhan. Sementara itu pada wanita muncul pada usia di awal tiga puluhan. Skizofrenia merupakan penyakit otak yang timbul akibat ketidak seimbangan pada dopamin, yaitu salah satu sel kimia dalam otak. Ia adalah gangguan jiwa psikotik paling lazim dengan ciri hilangnya perasaan afektif atau respons emosional dan menarik diri dari hubungan antar pribadi normal. Sering kali diikuti dengan delusi (keyakinan yang salah) dan halusinasi (persepsi tanpa ada rangsang pancaindra).

Dalam penelitian kali ini, penulis akan berfokus pada kemampuan reseptif dan produktif pengidap skizofrenia, karena kedua hal tersebut sangat penting dalam hubungan interaksi antara pengidap skizofrenia dengan para anggota keluarga, lingkungan sosial, para dokter, dan para perawat dalam menggunakan proses berbicara. Abbas (2006: 125) menyebutkan bahwa untuk menentukan kemampuan berbahasa pada seseorang haruslah meliputi keempat faktor kemampuan yang terbagi ke dalam dua keterampilan pokok. Pertama, keterampilan reseptif yaitu merupakan kegiatan penerimaan kode-kode bahasa yang disampaikan untuk kemudian dipahami oleh penerima (decode), termasuk di dalamnya ialah kemampuan membaca dan menyimak. Kedua, keterampilan produktif yaitu proses pelahiran kode bahasa atau kemampuan menghasilkan (encode), di dalamnya terdapat kemampuan berbicara dan menulis. Dari Keempat faktor itu, pemulis membatasi hanya dua faktor yang akan dijadikan acuan untuk menentukan kemampuan berbicara yaitu kemampuan menyimak dan berbicara. Adapun pada penelitian ini penulis menandai pasien skizofrenia dengan istilah pengidap bukan penderita seperti yang biasa masyarakat pada umunya utarakan, karena pada prinsipnya pasien skizofrenia mereka tidak ingin dikategorikan sebagai penderita yang memiliki konotasi negatif seolah mereka tersiksa dan menderita dalam penyakit yang mereka miliki, maka sebenarnya pasien skizofrenia lebih senang dan lebih merasa dihargai ketika istilah penderita dihilangkan dan diganti dengan pengidap yang memiliki makna lebih halus dibandingkan penderita. Oleh karena itu dalam penelitian ini penulis menggunakan istilah pengidap skizofrenia dalam menami pasien tersebut. 
Adapun penelitian terkait yang relevan dengan penelitian ini di antaranya ialah: (1) Kemampuan Bahasa Verbal Penderita Skizofrenia: Sebuah Studi Kasus yang ditulis oleh Rizkhi Nurul Azizah, penelitian tersebut membahas kebahasaan pada pengidap skizofrenia melalui kajian pragmatik dengan prinsip kerja sama teori Grace, yaitu menentukan maksim kuantitas dan kualitas terhadap ujaran pengidap skizofrenia. (2) Kajian Psikolinguistik Bahasa Skizofrenik:Studi Kasus pada Rumah Sakit Jiwa Bangli yang ditulis oleh $\mathrm{Ni}$ Ketut Alit Ida Setianingsih, I Made Netra, dan I Gst. Ngurah Parthama, penelitian tersebut mengemukakan bahwa produksi-produksi ujaran yang dihasilkan oleh pengidap skizofrenia melalui beberapa tahapan, dalam penelitian itu dijelaskan gejalagejala Bahasa yang ditimbulkan. (3) Defisit Pragmatik Tuturan Penderita Skizofrenia di RS Jiwa Menur Surabaya: Kajian Pragmatik Klinis yang ditulis oleh Yunita Suryani, dalam penelitian tersebut menjelaskan defisit tindak tutur yang dihasilkan oleh pengidap skizofrenia. Berbeda dengan ketiga penelitian sebelumnya yang telah disebutkan di atas dalam penelitian ini penulis akan mengedepankan hasil penelitian pada kemampuan berbahasa reseptif dan produktif dalam praktik berbicara pada pengidap skizofrenia.

\section{METODE}

Data pada penelitian ini diperoleh dengan menggunakan teknik simak libat cakap dan catat, yaitu peneliti melakukan penyadapan dengan cara berpartisipasi sambil menyimak dalam pembicaraan, serta mencatat data yang diperoleh dan mengklasifikasikannya, selain teknik tersebut peneliti juga menggunakan teknik cakap pancing yang merupakan suatu teknik yang diwujudkan dengan cara pemancingan karena untuk mendapatkan data tersebut peneliti harus memancing informan agar mau berbicara. Selain itu juga, penulis menggunakan metode padan untuk menganalisis data. Menurut Surdayanto (1993) Metode padan adalah metode/cara yang digunakan dalam upaya menemukan kaidah dalam tahap analisis data yang alat penentunya di luar, terlepas, dan tidak menjadi bagian dari bahasa (langue) yang bersangkutan. Metode padan yang digunakan dalam analisis ini ialah padan dengan organ wicara-fonetis artikulatoris yang menjadi alat ucap, penelitian yang menganilisis pada organ bicara manusia yang mengkaji terkait ujaran-ujaran fonetis. Dalam penelitian ini organ wicara dari pasien pengidap skizofrenia diuji dengan sistem kemampuan reseptif dan produktif yaitu disediakan beberapa bentuk huruf abjad dalam bahasa Indonesia untuk kemudian peneliti menganalisis cara pengucapan dari anak-anak penyandang tunagrahita tersebut.

Adapun metode pendekatan penyajian yang digunakan dalam penelitian ini ialah metode deskriptif yaitu memberikan penjelasan secara rinci dengan memberi ulasan mengenai suatu permasalahan yang menjadi objek penelitian. Dalam penelitian ini, sumber data yang diperoleh berasal dari seorang pasien di salah satu Rumah Sakit Jiwa (RSJ) di Kota Bandung yang mengidap penyakit skizofrenia sebagai informan. Penelitian dilakukan dengan rentan waktu satu bulan terhitung dari tanggal 12 Oktober sampai. 9 November 2020. Data yang akan digunakan merupakan data hasil uji kemampuan berbahasa Indonesia yang kemudian akan dianalisis lebih dalam menurut kajian fonologi.

\section{HASIL DAN PEMBAHASAN Kemampuan Reseptif} Kemampuan reseptif ialah kemampuan penerimaan dalam penelitian ini ialah proses menyimak yang 
menghasilkan jawaban berupa beberapa ujaran dari informan sebagai berikut.

\section{Data I}

"wulang jauh k humah mau"

Pada ujaran di atas terdapat kesalahan fonem yang terjadi pada beberapa kata seperti kata wulang yang dimaksudkan adalah kata pulang, fonem $/ \mathrm{p} /$ berubah menjadi fonem /w/ sehingga menghasilkan kata yang tidak memiliki arti dalam bahasa Indonesia. Begitu pun pada kata humah yang hendak diujarkan oleh informan ialah kata rumah perubahan terjadi dari fonem $/ r /$ menjadi fonem $/ h /$, kata humah sendiri tak memiliki arti dalam bahasa Indonesia. Maka sesungguhnya yang hendak diujarkan oleh informan ialah pulang jauh ke rumah mau, dalam pola kalimat pun tidak beraturan karena yang dimaksudkan seharusnya ialah mau pulang ke rumah yang jauh.

\section{Data II}

"Itu kura yang kena batunya."

Dalam ujaran di atas terdapat kesalahan fonem /e/ menjadi /u/ yang terdapat pada kata kura, makna kata yang dimaksud oleh informan adalah kera. Kesalahan fonem ini mengakibatkan kerancuan dalam makna yang ingin disampaikan pada mulanya. Apakah kurakura, kura atau kera kata yang sebenarnya ingin disampaikan, karena masing-masing dari kata tersebut memilki makna tersendiri, seperti di bawah ini:

a) ku.ra $n$ limpa.

b) ku.ra-ku.ra $n 1$ binatang melata berkaki empat, punggungnya berkulit keras, hidup di air dan di darat; Testudinata; 2 sesuatu yang bentuknya seperti (punggung) kurakura; 3 induk kunci gantung: repuhrepuh (KBBI V dalam jaringan)

c) ke.ra $n$ binatang menyusui (yang tergolong paling sempurna), bentukinya mirip manusia, berbulu pd seluruh tubuhnya, memiliki otak yang relatr lebih besar dan lebih cerdas pd hewan lain, termasuk hewan pemakan buan, biji-bijian, dsb. (KBBI V dalam jaringan)

Dari analisis ini bisa kita lihat bahwa informan salah mengucapkan fonem pada kata kera.

\section{Data III}

"Saya kerja di Lapindo udah empat bulan. Lapindo yang di BEC."

Pada ujaran di atas terjadi kesalahan fonem yang mengakibatkan salah faham dalam faktual. Kita ketahui bahwa Lapindo itu berada di Sidoarjo Jawa Timur, bukan di BEC (Bandung Elektronik Center). Namun Responden menuturkan bahwa dia keria di Lapindo yang berada di BEC (Bandung Electronik Center).

Setelah ditanyakan berulang kali barulah Responden mengatakan Rafindo bukan Lapindo setelah menunjukkan bukti amplop yang ada kop surat Rafindo. Fonem /r/ berubah menjadi /1/ dan fonem /f/ menjadi /p/ menjadikan kesalahpahaman karena Lapindo dan Rafindo itu sendiri berbeda keberadaannya. Jika Lapindo itu tidak ada maka maksud yang dituju itu Rafindo. Bentuk ujaran selanjutnya dari informan setelah diucapkan berapa kali "Saya kerja di Rafindo udah empat bulan. Rafindo yang di BEC"

\section{Data IV}

"Mandi pake sampo lipeboy"

Pada ujaran di atas terdapat kesalahan fonem, /f/ digantikan oleh /p/. Hal ini mengakibatkan kerancuan dalam hal makna awal yang ingin disampaikan oleh informan, karena pendengar akan sedikit kebingungan dengan kata lipeboy. Sedangkan kata yang sebenarnya adalah lifebouy yang pengucapannya menjadi laifboy, terpengaruh oleh faktor kebahasaan daerah informan, yaitu bahasa 
Sunda yang memang kesulitan mengucapkan fonen /f/.

\section{Data V}

"kemarin jatoh di belokan haha baseuh pisan"

Dalam ujaran di atas terlihat kesalahan pengucapan fonem $/ o /$ pada kata jatoh seharusnya ialah fone $/ u /$ menjadi kata jatuh. Apabila diamati kata belokan dalam bahasa Indonesia berarti sebuah tikungan yang berkelok, berlekuk. Memang secara susunan kalimat sudah betul, hanya saja jika dilihat kata belokan dalam kalimat tersebut yang dimaksudkan informan adalah kata selokan karena bisa dilihat pada pendamping kanan kata tersebut ada frasa baseuh pisan dalam bahasa Sunda yang dalam bahasa Indonesia berarti basah sekali, sehingga secara makna tidak mungkin apabila jatuh di belokan akan menimbulkan sesuatu yang basah, tetapi yang jatuh dalam keadaan basah pasti jatuh ke dalam selokan, karena kata selokan bermakna parit. Selain itu juga, informan menggabungkan kata-kata dalam bahasa Sunda dengan bahasa Indonesia karena memang faktor bahasa Ibu dari informan yang berlatar belakang bahasa Sunda.

\section{Data VI}

"hayang jalan-jalan ka gunung merapi yang sangkuriang"

Pada ujaran di atas terjadi gangguan dalam pengungkapan suatu tempat yang dimaksudkan namun tidak berada di posisi tempat yang seharusnya. Dalam ujaran informan mengatakan ingin jalan-jalan ke gunung merapi letak gunung tersebut berada di daerah provinsi Jawa Tengah, tetapi yang dimaksudkan informan bukan gunung tersebut karena apabila dilihat ujaran selanjutnya ialah yang sangkuriang, kata tersebut merupakan sebuah simbol yang identik dengan sebuah gunung yang letaknya ada di Jawa Barat yaitu Gunung Tangkuban Parahu sehingga yang dimaksudkan informan ialah gunung tangkuban parahu bukan gunung merapi, hanya saja informan memiliki pengetahuan bahwa gunung tersebut merupakan gunung berapi juga.

Ganggunag berbahasa yang ditimbulkan juga hampir sama dan berulang seperti ujaran yang lain yaitu penggunaan bunyi-bunyi bahasa Ibu yang diujarkan oleh informan kata haying yang memiliki arti dalam bahasa Indonesia mau atau menginginkan sesuatu serta konjungsi $k a$ dalam bahasa Sunda yang dalam bahasa Indonesia seharusnya menggunakan konjungsi ke.

\section{Data VII}

"aya musik asik ehh apa loyang barengbareng joget"

Dalam ujaran di atas, ada bunyi fonem dari sebuah kata yang berubah yaitu kata loyang mengalami perubahan dari goyang loyang dalam bahasa Indonesia memiliki arti tembaga kuning (kuningan): gansa atau bermakna alat untuk memasak yang biasanya digunakan untuk membuat kue dan sejenisnya. Hal tersebut jelas tidak memiliki relevansi dengan pendamping kanan kata tersebut loyang bareng-bareng joget karena kata joget memiliki makna menari sebuah tarian. Oleh karena itu ujaran yang hendak diucapkan oleh informan ialah kata goyang yang dalam KBBI berarti bergerak berayun-ayun, dari arti kata tesebut jelas memiliki korelasi dan relevan dengan makna kata joget. Perubahan fonem terjadi dari fonem $/ g /$ menjadi fonem $/ l /$ yang membuat berubah juga arti dan makna kata tersebut.

\section{Data VIII}

"Rumahnya di manah? rumahnya rumah siapah? Rumahnya siapah? Rumah kamu siapah? Rumah si-rumah rumah siapah? Di mana rumahmu?"

Pada ujaran di atas informan melakukan pengulangan dengan tujuan 
untuk memperbaiki ujarannya. Informan memperbaiki ujarannya karena setelah kata rumah, kata yang selanjutnya diujarkan mengalami kesalahan sebab kata setelahnya tidak sesuai dengan apa yang ditanyakan. Kata rumah merupakan kelas kata nomina atau kata benda. Bedanya, informan tidak mengulangi kata yang bersinonim, tetapi mengulang kata yang sama sebanyak sembilan kali hingga ujaran tersebut sesuai dengan apa yang ingin ujarkan, kata yang diulang iyalah kata rumah pada ujaran (1) rumahnya di mana? (2) rumahnya (3) rumah siapa? (4) rumahnya siapa? (5) rumah kamu siapa? (6) rumah si (7) rumah (8) rumah siapa? (9) dimana rumahmu.

Secara pola kalimat pun, susunan yang dihasilkan oleh informan tidak sesuai dengan kaidah bahasa Indonesia. Seerti ujaran rumah kamu siapa? Seharusnya bila ingin menjadikannya sebagai kalimat pertanyaan ialah rumah kamu dimana? dan kamu siapa? Bukan rumah kamu siapa? Sehingga meninmbulkan keambiguitasan dalam sebuah pertanyaan. Kemudian dalam setiap ujaran yang berakhiran fonem /a/ informan sering sekali menambahkan bunyi fone $/ \mathrm{h} /$ di akhir kata seperti berikut. Bunyi di mana menjadi di manah, bunyi siapa menjadi siapah.

\section{Data IX}

"cita-cita jadi Tee hhhm Tee Tee en eh Te En em tentara deh"

Pada ujaran di atas informan mengalami kebingungan dalam mengucapkan sesuatu yang ada pada pikirannya, kata yang hendak diucapkan informan ialah TNI (tentara Nasional Indonesia) tetap dalam prosesnya informan mengalami jeda dan meralat yang ingin diucapkan menjadi tentara. Dalam proses perubahan dari TNI ke tentara informan melakukan pengulangan pada beberapa bunyi /te/ kemudian sempat menambahkan bunyi $/ \mathrm{hhmm} /$ atau bergeram sebagai jeda saat proses berfikir. Meskipun makna yang dihasilkan sama dari TNI menjadi tentara karena TNI merupakan kepanjangan dari Tentara Nasional Indonesia, namun dalam fonologi secara ujaran pengucapan yang dilakukan oleh informan mengalami gangguan berbahasa yaitu pengulangan dan jeda.

\section{Data X}

"aku marah hhhmmm karena ituh hhhmm karena apah tapi marah"

Pada ujaran di atas informan tidak menuturkannya secara lengkap sehingga menjadi sebuah kalimat. Seperti pada gangguan berbahasa pada kasus sebelumnya, pada ujaran di atas pun informan mengalami jeda cukup lama dengan bunyi $/ \mathrm{hhhmm} /$. Jeda terjadi cukup lama sebgai proses berfikir informan. Pada jeda tersebut informan lupa dengan alasan yang harus ia berikan sehingga ia membutuhkan waktu untuk berpikir atau mengarang alasan yang masuk akal. Namun ternyata informan mengulang kata karena yang dilanjutkan dengan kata apa yang mengalami pemanjangan dan penambahan fonem konsonan $/ h /$ di akhir kata tesebut. Kata apa tersebut digunakan oleh informan sebagai pengisi jeda karena ia masih belum menemukan alasan yang tepat dan karena terlanjur berujar sehingga ia membutuhkan waktu untuk berpikir. Tetapi, setelah mengulangi kata apa tersebut, informan tidak mengeluarkan ujaran yang menyatakan alasan untuk melengkapi ujaran tersebut, akan tetapi informan justru menambahkan konjungsi tapi untuk melanjutkan ujarannya yang belum selesai dan tetap tidak selesai karena ia tidak memberikan intonasi final mengakhiri sebuah kalimat, maka dengan demikian informan memang tidak menyelesaikan ujarannya dalam kalimat tersebut. 


\section{Kemampuan Produktif}

Kemampuan produktif meliputi kemampuan berbicara, yaitu kemampuan menghasilkan bunyi-bunyi ujaran yang ingin disampaikan oleh informa, dalam prosesnya uji kemampuan berbicara menggunakan instrumen berupa gambar untuk memancing informan dalam penyebutan bunyi-bunyi tertentu. Berikut hasil pelafalan dari informan.

Tabel 1. Kemampuan Pelafalan Informan

\begin{tabular}{|c|c|c|c|}
\hline No & Jenis I & ata & Dilafalkan \\
\hline 1 & \multirow{10}{*}{ Bilangan } & satu & [au] \\
\hline 2 & & dua & [ua] \\
\hline 3 & & tiga & [giga] \\
\hline 4 & & empat & [impat ] \\
\hline 5 & & lima & [lima] \\
\hline 6 & & enam & [ənam] \\
\hline 7 & & tujuh & [jujuh] \\
\hline 8 & & delapan & [papan] \\
\hline 9 & & sembilan & [dilan] \\
\hline 10 & & sepuluh & [uluh] \\
\hline 11 & \multirow{5}{*}{$\begin{array}{l}\text { Buah- } \\
\text { buahan }\end{array}$} & jeruk & [uuu-uuu?] \\
\hline 12 & & alpukat & [pu?at] \\
\hline 13 & & apel & [apəl] \\
\hline 14 & & melon & [meon] \\
\hline 15 & & pisang & [nana] \\
\hline 16 & \multirow{5}{*}{ Binatang } & burung & [buun] \\
\hline 17 & & ikan & [ikhan] \\
\hline 18 & & sapi & [moö] \\
\hline 19 & & ular & [uyar] \\
\hline 20 & & kucing & [kucin] \\
\hline 21 & \multirow{5}{*}{ Transportasi } & bis & [tayo] \\
\hline 22 & & motor & [motor] \\
\hline 23 & & mobil & [mobil] \\
\hline 24 & & kereta & $\begin{array}{c}\text { [pipi } \\
\text { tututut] }\end{array}$ \\
\hline 25 & & pesawat & [kapal] \\
\hline 26 & \multirow{5}{*}{ Pancaindera } & mata & [mata] \\
\hline 27 & & mulut & [muwut] \\
\hline 28 & & telinga & [yaya] \\
\hline 29 & & hidung & [hidun] \\
\hline 30 & & tangan & [yanyan] \\
\hline
\end{tabular}

Pada kemampuan berbicara informan, seperti digambarkan dalam tabel informan tidak dapat berbicara dengan jelas dan cenderung hanya memainkan lidah dan mulut saja. Proses pemancingan melalui instrumen yang diberikan untuk mengetahui kemampuan berbicara informan memerlukan waktu yang cukup lama, informan sangat lambat dalam menangkap gambar yang diperlihatkan kepadanya, dan berfikir mencoba memperhatikan dengan mulut yang terbuka. Setelah menunggu cukup lama, informan perlahan mulai berbicara dan menyebutkan gambar-gambar yang berada pada instrumen penelitian yang terdiri dari jenis kosakata sehari-hari di lingkungan sekitar, meskipun informan lama dalam berbicara tetapi pemahaman dan ketepatan informan pada kosakata yang diberikan termasuk baik untuk pengidap gangguan kejiwaan. Penyebutan huruf informan sudah jelas tidak mampu seperti yang telah dibahas pada proses membaca, sedangkan untuk menyebutkan angka informan mampu berhitung dari angka 1 sampai dengan 10 dengan perlahan, dan terbata-bata.

Pelafalan dan kejelasan informan dalam berbicara terbilang sulit dimengerti oleh lawan bicara, karena kemampuan pola pikir yang suda tidak seperti orang normal sehingga membuat informan kesulitan berbicara. Terlihat pada tabel di atas informan mengucapkan kosakata hanya dengan mengucapkan fonem-fonem belakangnya saja, beberapa kesalahan dan ketidakjelasan informan dalam berbicara yaitu menghilangkan fonem-fonem, seperti:

Tabel 2. Galat Penghilangan Fonem

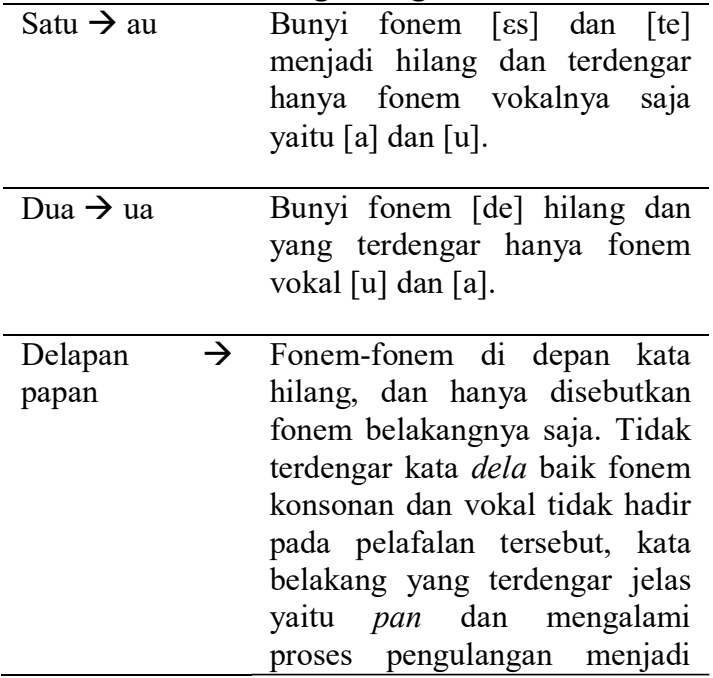


Studi Pendidikan Bahasa dan Sastra Indonesia

FKIP Universitas Kuningan

\begin{tabular}{|c|c|}
\hline & papan. \\
\hline Sepuluh $\rightarrow$ uluh & $\begin{array}{l}\text { Pelafalan sepuluh suku kata } \\
\text { awal lebur dan terdengar suku } \\
\text { kata belakang saja yaitu } u l u h .\end{array}$ \\
\hline $\begin{array}{l}\text { Alpukat } \quad \rightarrow \\
\text { pukat }\end{array}$ & $\begin{array}{l}\text { Pelafalan suku kata depan } \\
\text { hilang, hanya terdengar suku } \\
\text { kata belakang pukat. }\end{array}$ \\
\hline Melon $\rightarrow$ meon & $\begin{array}{l}\text { Bunyi fonem yang hilang pada } \\
\text { kata ini berada pada tengah } \\
\text { kata, yaitu fonem konsonan } \\
{[\varepsilon l] \text {, tidak banyak bunyi fonem }} \\
\text { yang hilang, bahkan fonem } \\
\text { konsonan dapat sedikit } \\
\text { terdengar jelas pada kata } \\
\text { tersebut, tidak beberapa kata } \\
\text { lain yang hanya terdengar } \\
\text { fonem vokalnya saja. }\end{array}$ \\
\hline $\begin{array}{l}\text { Burung } \\
\text { buung }\end{array}$ & $\begin{array}{l}\text { Bunyi fonem yang hilang } \\
\text { berada di tengah kata sama } \\
\text { seperti kata melon } \rightarrow \text { meon, } \\
\text { hilangnya fonem }[\varepsilon l] \text {, dan pada } \\
\text { kata burung } \rightarrow \text { buung, } \\
\text { hilangnya fonem }[\varepsilon r] .\end{array}$ \\
\hline
\end{tabular}

Selain penghilangan fonem yang dilakukan informan saat berbicara, kesalahan yang dilakukan informan pun ialah adanya perubahan fonem dan pengulangan fonem pada beberapa kata saat berbicara.

Tabel 3. Galat Perubahan dan Pengulangan Fonem

\begin{tabular}{ll}
\hline Tiga $\rightarrow$ giga & $\begin{array}{l}\text { Perubahan fonem [te] } \\
\text { menjadi fonem [ge] }\end{array}$ \\
\hline Empat $\rightarrow$ impat & $\begin{array}{l}\text { Perubahan fonem [e] } \\
\text { menjadi fonem [i] }\end{array}$ \\
\hline Sembilan $\rightarrow$ dilan & $\begin{array}{l}\text { Penghilangan beberapa } \\
\text { fonem dan perubahan } \\
\text { fonem } \\
\text { fonem [de] }\end{array}$ \\
\hline Ular $\rightarrow$ uyar & $\begin{array}{l}\text { Perubahan terjadi pada } \\
\text { tengah kata dari fonem } \\
\text { [el] menjadi fonem [ye] }\end{array}$ \\
\hline Mulut $\rightarrow$ muwut & $\begin{array}{l}\text { Perubahan terjadi pada } \\
\text { tengah kata dari fonem } \\
\text { [el] menjadi fonem [we] }\end{array}$ \\
\hline Tujuh $\rightarrow$ jujuh & Pengulangan pada suku \\
\hline
\end{tabular}

\begin{tabular}{|c|c|}
\hline & kata terakahir \\
\hline Jeruk $\rightarrow$ uuk-uuk & $\begin{array}{l}\text { Perubahan dan } \\
\text { penghilangan fonem serta } \\
\text { pengulangan }\end{array}$ \\
\hline Telinga $\rightarrow$ ya ya & $\begin{array}{lll}\text { Pegulangan } & \text { suku } & \text { kata } \\
\text { terakhir } & & \end{array}$ \\
\hline Tangan $\rightarrow$ yanjan & $\begin{array}{l}\text { Pengulangan suku kata } \\
\text { terakhir }\end{array}$ \\
\hline
\end{tabular}

Sementara itu, pada intonasi dan tekanan suara saat berbicara cukup dikatakan stabil meski suara kadang terdengar kecil atau seolah berbisik, lawan bicara tetap bisa mendengar yang dikatakan oleh informan. Adapun ketepatan kosakata terhadap instrumen yang diberikan, beberapa kata tidak sesuai dengan bahasa Indonesia yang baik dan benar, misalnya:

1. Pisang $\rightarrow$ nana

Banana (bahasa Inggris dari pisang)

\section{Sapi $\rightarrow$ moo}

Suara dari binatang tersebut yang biasanya didengar informan dengan bunyi mow.

\section{Bis $\rightarrow$ tayo}

Sebuah tokoh kartun yang diimajinasikan dalam bentuk kendaraan tersebut, yang biasanya ditonton oleh anak-anak pada salah satu stasiun televisi.

4. Kereta $\rightarrow$ tut-tut

Suara dari kendaraan tersebut, yang bentuknya memanjang dan terdiri dari beberapa gerbong.

5. Pesawat $\rightarrow$ kapal

Kata kapal sering digunakan di lingkungan sekitarnya untuk mempermudah penyebutan pesawat, sehingga informan mengucapkan kapal bukan pesawat. 
Informan memang tidak dapat berbicara secara sempurna dengan pelafalan yang jelas, tetapi informan memiliki kemampuan komunikasi yang dapat diterima oleh lawan bicaranya karena memiliki kekuatan interaksi yang baik. Informan mampu diajak berbincang dan bercerita ketika lawan bicara bertutur, meski memang emosinya tidak stabil dan butuh bimbingan dan penanganan khusus.

\section{KESIMPULAN}

Berdasarkan pemaparan hasil analisis penelitian tersebut maka dapat disimpulkan beberapa hal mengenai kemampuan berbahasa dalam praktik berbicara pada pengidap skizofrenia ialah sebagai berikut. (1) Dalam proses kemampuan reseptif yaitu menyimak, informan menanggapi dengan cukup kesulitan karena daya tangkap dan konsentrasi yang tidak stabil terhadap kejiwaan informan. Selain itu juga ujaranujaran yang dihasilkan cenderung bersifat manasuka tidak sesuai dengan sebagaimana ujaran itu hendak disampaikan, terjadi beberapa gangguan berbahasa dalam proses praktik berbicara pada saat mengutarakan jawaban, seperti: (1) kesalahan penggunaan fonem yang menimbulkan perbedaan arti dan makna seperti pada kata goyang yang berubah menjadi loyang. Hal-hal tersebut menimbulkan keambiguan dan kesalahpahaman dalam proses berbicara, (2) kesalahan penggunaan preposisi dan konjungsi, cenderung penempatan dua bentuk kategori kata tersebut disimpan sembarang oleh informan, (3) penggunaan kata imbuhan yang tidak sesuai, (4) tuturan yang diujarkan kebanyakan tidak sesuai dengan pola susunan kalimat yang sesuai dengan kaidah bahasa Indonesia. (2) Dalam proses kemampuan produktif yaitu berbicara, informan cukup mampu berceloteh sesuai dengan keinginannya, hanya saja ketika diberikan instrument berupa gambar untuk memancing aktifitas berbicara informan terdapat banyak galat yang terjadi seperti: (1) penghilangan fonem awal, tengah, maupun akhir, (2) penambahan dan pengurangan fonemfonem tertentu, (3) pengulangan fonemfonem khususnya pada fonem tengah, serta (4) ketidaktepatan kosakata dengan ujaran informan karena faktor pengaruh bahasa Ibu atau bahasa asing yang dikuasai oleh informan.

Secara keseluruhan memang pengidap skizofrenia tidak mampu berbicara layaknya manusia pada umumnya, karena faktor pengusaan kognitif yang sudah tidak berfungsi dan berjalan seperti sedia kala, tetapi seiring bergulirnya waktu dengan pengobatan dan terapi yang terus dilakukan kesehatan pada kejiwaan pasien skizofrenia akan dapat pulih kembali..

\section{DAFTAR PUSTAKA}

Abbas, S. (2006). Pembelajaran Bahasa Indonesia yang Efektif di Sekolah Dasar. Jakarta: Depdiknas.

Arifudin. (2013). Neuropsikolingustik. Jakarta: Rajawali Pers.

Azizah, R. N. (2014). Kemampuan Bahasa Verbal Penderita Skizofrenia: Sebuah Studi Kasus. Skriptorium, Vol.2 No.2, 97-105.

Chaer, A. (2015). Psikolinguistik Kajian Teoritik. Jakarta: Rineka Cipta.

Chaer, A. (2014). Linguistik Umum. Jakarta: Rineka Cipta.

Dardjowidjojo. (2003). Psikolinguistik Pengantar Pemahaman Bahasa Manusia. Jakarta: Yayasan Pustaka Obor Indonesia.

Dardjowidjojo. (2018). Echa Kisah Pemerolehan Bahasa Anak Indonesia. Jakarta: Universitas Katolik Indonesia Atma Jaya.

Kridalaksana, H. (2008). Kamus Linguistik Edisi Keempat. Jakarta: PT. Gramedia Pustaka Utama. 
Mahpudin, P. (2016). Asesmen Membaca Permulaan. Bandung: Simposium.

Mar'at, S. (2015). Psikologi Perkembangan. Bandung: Remaja Rosdakarya.

Muhith, A. (2015). Pendidikan Keperawatan Jiwa, Teori dan Aplikasi. Yogyakarta: Penerbit Andi.

Pieter, H. Z., Bethsaida J., dan Marti S. (2011). Pengantar Psikopatologi untuk Keperawatan. Jakarta: Kencana Prenada Media.

Setianingsinh, Ida, N. K. A., Netra, I M.., Parthama, I G. N. (2009). Kajian Psikolinguistik Bahasa

Skizofrenik:Studi Kasus pada Rumah Sakit Jiwa Bangli. Logat: Jurnal Ilmiah Bahasa dan Sastra, Vol. 5 No.1, 38-44.

Subagyo, P. Joko. (2006). Metode Penelitian dalam Teori dan Praktek. Jakarta: Rineka Cipta.

Subyantoro. (2013). Gangguan Berbahasa Mengenali untuk
Mengantisipasi Sejak Dini. Yogyakarta: Penerbit Ombak.

Sudaryanto. (2015). Metode dan Aneka Teknik Analisis Bahasa: Pengantar Penelitian Wahana Kebudayaan Secara Linguistik. Yogyakarta: Duta Wacana.

Sugiyono. (2015). Metode Penelitian Kuantitatif, Kualitatif, dan $R$ dan $D$. Bandung: Alfabeta.

Suryani, Y. (2015). Defisit Pragmatik Tuturan Penderita Skizofrenia di RS Jiwa Menur Surabaya: Kajian Pragmatik Klinis. Jurnal Pena Indonesia, Vol. 1 No.2, 106-141.

Tarigan, H. G. 2015. Menyimak Sebagai Keterampilan Berbahasa. Bandung: Angkasa.

Tarigan, H. G. (2015). Berbicara Sebagai Keterampilan Berbahasa. Bandung: Angkasa.

Tarigan, H. G. dan Tarigan, D.. (1987). Teknik Pengajaran Keterampilan Berbahasa. Bandung: Angkasa. 